\title{
Properties of Spark Plasma Sintered Compacts and Magnetron Sputtered Coatings Made from Cr, Mo, Re and Zr Alloyed Tungsten Diboride
}

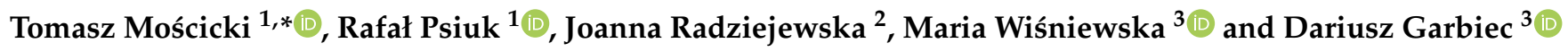 \\ 1 Institute of Fundamental Technological Research Polish Academy of Sciences, 5B Pawinskiego St., \\ 02-106 Warsaw, Poland; rpsiuk@ippt.pan.pl \\ 2 Faculty of Mechanical and Industrial Engineering, Warsaw University of Technology, Narbutta 85, \\ 02-524 Warsaw, Poland; jora@meil.pw.edu.pl \\ 3 Łukasiewicz Research Network - Metal Forming Institute, 14 Jana Pawla II St., 61-139 Poznan, Poland; \\ maria.wisniewska@inop.lukasiewicz.gov.pl (M.W.); dariusz.garbiec@inop.lukasiewicz.gov.pl (D.G.) \\ * Correspondence: tmosc@ippt.pan.pl
}

check for

updates

Citation: Mościcki, T.; Psiuk, R.; Radziejewska, J.; Wiśniewska, M.; Garbiec, D. Properties of Spark

Plasma Sintered Compacts and Magnetron Sputtered Coatings Made from $\mathrm{Cr}$, Mo, Re and $\mathrm{Zr}$ Alloyed Tungsten Diboride. Coatings 2021, 11, 1378. https://doi.org/10.3390/ coatings11111378

Academic Editor: Salvatore Grasso

Received: 22 October 2021

Accepted: 5 November 2021

Published: 10 November 2021

Publisher's Note: MDPI stays neutral with regard to jurisdictional claims in published maps and institutional affiliations.

Copyright: (c) 2021 by the authors. Licensee MDPI, Basel, Switzerland. This article is an open access article distributed under the terms and conditions of the Creative Commons Attribution (CC BY) license (https:/ / creativecommons.org/licenses/by/ $4.0 /)$.

\begin{abstract}
To enhance the properties of tungsten diboride, we have synthesized and characterized solid solutions of this material with chromium, molybdenum, rhenium and zirconium. The obtained materials were subsequently deposited as coatings. Various concentrations of these transition metal elements, ranging from 0.0 to 24.0 at.\%, on a metals basis, were made. Spark plasma sintering was used to synthesize these refractory compounds from the pure elements. Elemental and phase purity of both samples (sintered compacts and coatings) were examined using energy dispersive X-ray spectroscopy and X-ray diffraction. Microindentation was utilized to measure the Vickers hardness. $\mathrm{X}$-ray diffraction results indicate that the solubility limit is below 8 at.\% for Mo, Re and $\mathrm{Zr}$ and below 16 at.\% for Cr. Above this limit both diborides (W,TM) $B_{2}$ are created. Addition of transition metals caused decrease of density and increase of hardness and electrical conductivity of sintered compacts. Deposited coatings $\mathrm{W}_{1-\mathrm{x}} \mathrm{TM}_{\mathrm{x}} \mathrm{B}_{\mathrm{y}}(\mathrm{TM}=\mathrm{Cr}, \mathrm{Mo}, \mathrm{Re}, \mathrm{Zr} ; \mathrm{x}=0.2 ; \mathrm{y}=1.7-2)$ are homogenous, smooth and hard. The maximal hardness was measured for $\mathrm{W}-\mathrm{Cr}-\mathrm{B}$ films and under the load of $10 \mathrm{~g}$ was $50.4 \pm 4.7 \mathrm{GPa}$. Deposited films possess relatively high fracture toughness and for $\mathrm{WB}_{2}$ coatings alloyed with zirconium it is $\mathrm{K}_{1 \mathrm{c}}=2.11 \mathrm{MPa} \mathrm{m}^{1 / 2}$.
\end{abstract}

Keywords: ternary tungsten boride; spark plasma sintering; magnetron sputtering; electrical conductivity

\section{Introduction}

Nowadays the rise of a broad class of compounds comprising heavy transition metal (TM) and light-element atoms, like nitrides, carbides, and borides can be seen. Such compounds possess excellent mechanical properties such as high hardness and high wear resistance, refractory properties and also good thermal and electrical conductivity resulting from the concurrently high valence electron density and strong covalent bonding in these compounds [1,2]. These advanced ceramics can find applications in key technological fields, including cutting and drilling tools, wear resistant coatings, and engine components $[3,4]$. However, a major challenge remains in that the applications are to produce reliable tool components made of these materials in a relatively simple and time-consuming manner. This challenge is partly resolved by deposition of thin films [5-8] developing easily machinable materials [3] or new methods of sintering [9]. For better electro machining the good electrical conductivity is needed. Among such compounds, tungsten diborides $\left(\mathrm{WB}_{2}\right)$ alloyed with other TM are especially promising for their very high hardness accompanied with increased toughness and good electrical conductivity $[10,11]$. The theoretical studies have showed that $\mathrm{WB}_{2}$ doped by $\mathrm{TM}$ can possess the very high hardness above $40 \mathrm{GPa}[1,5]$. 
One of best candidates of $\mathrm{WB}_{2}$ alloying is rhenium (Re). Diboride of this metal is superhard and can crystalize in similar to $\mathrm{WB}_{2}$ hexagonal $\mathrm{AlB}_{2}$-type structure [12]. The addition of rhenium into the $W_{4}$ and $W_{2} B_{5}$ phases have been reported by Mohammadi et al. [13] and by Feng et al. [14]. With the addition of 1 at.\% Re, the Vickers microhardness increased to approximately $50 \mathrm{GPa}$ at $0.49 \mathrm{~N}$. Obtained tungsten tetraboride $\left(\mathrm{WB}_{4}\right)$ with 1 at.\% Re admixture is thermally stable up to approximately $400{ }^{\circ} \mathrm{C}$ in air. In the case of Re alloyed $\mathrm{W}_{2} \mathrm{~B}_{5}$ theoretical studies showed that $\mathrm{W}_{1.5} \operatorname{Re}_{0.5} \mathrm{~B}_{5}$ and $\mathrm{W}_{0.5} \mathrm{Re}_{1.5} \mathrm{~B}_{5}$ are energetically and thermodynamically stable. The calculated hardness of $\mathrm{W}_{2} \mathrm{~B}_{5}$ and $\mathrm{W}_{0.5} \operatorname{Re}_{1.5} \mathrm{~B}_{5}$ was 16.11 and $17.91 \mathrm{GPa}$, respectively. On the other hand, $\mathrm{ReB}_{2}$ alloyed by tungsten was studied experimentally by Lech et al. [15]. The solid solutions of tungsten in $\operatorname{ReB}_{2}$ have been successfully synthesized by using an electric-arc furnace. The solubility limit for tungsten in $\mathrm{ReB}_{2}$ is nearly 48 at.\%, which indicates a very high degree of solubility. The studies showed also that $\mathrm{ReB}_{2}$ structured compounds are superhard and may warrant further studies into additional solid solutions or ternary compounds taking this structure type. By using first-principles calculations, the structure and elastic properties of $\operatorname{Re}_{x} W_{1-x} B_{2}$ alloys $(x=0.1-0.9)$ with the $R_{e} B_{2}$ like structure were studied by Yufei Tu et al. [16]. It was found that $\operatorname{Re}_{0.4} \mathrm{~W}_{0.6} \mathrm{~B}_{2}$ has both high bulk modulus ( $360 \mathrm{GPa}$ ) and high shear modulus (291 GPa). The authors show that there is a pseudogap at the Fermi level, which indicates that the $\operatorname{Re}_{0.4} W_{0.6} B_{2}$ is stable. The superior elastic property suggests the $\operatorname{Re}_{0.4} W_{0.6} B_{2}$ is desired as a potential hard material. Shaw [10] showed that addition of molybdenum (Mo) to $\mathrm{WB}_{2}$ significantly improves wear resistance. The formation of $\mathrm{WB}_{2}$ and $\mathrm{MoB}_{2}$ hard phases with $\mathrm{AlB}_{2}$-type structure is most likely the reason for the very low wear volume. In this case, the wear volume decreases from $1.00 \times 10^{7}\left(\mathrm{WB}_{2}\right)$ to $3.22 \times 10^{6} \mu \mathrm{m}^{3}$ for $\mathrm{WB}_{2}-\mathrm{MoB}_{2}$ binary compound. Additionally, corrosion resistance of $\mathrm{WB}_{2}$ ceramic was improved. In the case of alloying with zirconium ( $\mathrm{Zr})$ [9], the spark plasma sintered compacts are characterized by a specific wear rate in the range of $1 \times 10^{-6}-3 \times 10^{-5} \mathrm{~mm}^{3} / \mathrm{Nm}$. The friction and wear test results reveal the formation of a boron-based film which seems to play the role of solid lubricant. This effect demonstrates the possibility to use sintered W-Zr-B materials to make machining tools and various components work in harsh conditions. With an increasing zirconium content, the electrical conductivity of the SPSed specimens increased both in $\mathrm{W}_{1-\mathrm{x}} \mathrm{Zr}_{\mathrm{x}} \mathrm{B}_{4.5}$ and $\mathrm{W}_{1-\mathrm{x}} \mathrm{Zr}_{\mathrm{x}} \mathrm{B}_{4.5}(0<\mathrm{x} \leq 0.24)$. $\mathrm{W}_{0.76} \mathrm{Zr}_{0.24} \mathrm{~B}_{2.5}$ sintered at a 24 min holding time is characterized by the highest electrical conductivity of $3.961 \times 10^{6} \mathrm{~S} / \mathrm{m}$, which is similar to the electrical conductivity of WC-Co cemented carbides [9]. In the case $\mathrm{WB}_{4}$ alloyed with chromium (Cr), Mohammadi et al. [13] showed that addition of $10 \mathrm{at} . \% \mathrm{Cr}$ on a metals basis results in an increase in microhardness (at $0.49 \mathrm{~N}$ ) from $43.3 \pm 2.9 \mathrm{GPa}$ for pure $\mathrm{WB}_{4}$ to $53.5 \pm 1.9 \mathrm{GPa}$ and the defect structure of this material may be responsible for the hardening trends observed for the solid solutions.

As it was shown by Garbiec et al. [9], it is possible to synthesize in one stage fast process the $\mathrm{W}_{1-\mathrm{x}} \mathrm{Zr}_{\mathrm{x}} \mathrm{B}_{2}$ ceramic with properties competitive to the widely used WC-4Co sintered compacts. Additionally, until now there has been no information about the use of $\mathrm{WB}_{\mathrm{x}}$ alloyed by $\mathrm{Re}, \mathrm{Mo}, \mathrm{Cr}, \mathrm{Zr}$ as a coatings deposited by magnetron sputtering (MS). However, addition of other transition metals such as tantalum (Ta) [11] or titanium (Ti) [6,17] to $\alpha$ $\mathrm{WB}_{2}$ lattice can cause combining of high strength with high fracture toughness in deposited coatings. Deposited films are superhard $(\mathrm{H}>40 \mathrm{GPa})$ and in the case of tantalum can exhibit fracture toughness $\mathrm{K}_{1 \mathrm{c}}$ values of 3.7 to $3.0 \mathrm{MPa} \cdot \mathrm{m}^{1 / 2}$ for increasing Ta content (single-phased up to 26 at.\% Ta) [11]. Psiuk et al. [18] studied W-Zr-B coatings deposited by a hybrid process combining pulsed laser deposition of $\mathrm{ZrB}_{2}$ and radio frequency magnetron sputtering of $\mathrm{W}_{2} \mathrm{~B}_{5}$. Deposited films with $\approx 1 \%$ atomic content of $\mathrm{Zr}$ were superhard $(\mathrm{H}=40 \pm 4 \mathrm{GPa})$ and incompressible $\left(\mathrm{R}_{\mathrm{s}}=12 \pm 1 \mathrm{GPa}\right)$ but possessed a relatively low Young's modulus $(E=330 \pm 32 \mathrm{GPa})$ and a high elastic recovery $\left(\mathrm{W}_{\mathrm{e}}=0.9\right)$. The above promising results suggest the need for further research.

Currently, there are only two commercially relevant superhard materials: diamond and cubic boron nitride [3]. Although diamond can be used to cut through rock, it cannot be used to cut steel due to a chemical reaction that forms iron carbide. Instead, cubic boron 
nitride is used to cut and mill ferrous metals. In some ways, it is remarkable that humanity has achieved so much in terms of industrial machining, drilling, and polishing, relying on just two high-end compositions. In this work novel materials in the form of compacts and protective coatings are presented. As it is shown in the above literature and on the basis of our research it can be concluded that alloyed $\mathrm{WB}_{2}$ with $\mathrm{Cr}, \mathrm{Mo}, \mathrm{Re}$ or $\mathrm{Zr}$ can be competitive to widely used WC-Co. Proposed materials possess greater hardness and $20 \%$ lower density than WC. The alloying with transition metals additionally improves elastic and conductive properties of these materials. Because WC is quite brittle, binders such as cobalt are currently added to improve ductility, but such addition comes at the expense of hardness and additionally Co is toxic. The materials proposed by us may in the future replace tungsten carbide and may find many industrial applications, such as highperformance cutting tools and wear-protective coatings. In addition, $\mathrm{W}-\mathrm{TM}-\mathrm{B}$ coatings were investigated due to their excellent mechanical properties, i.e., very high hardness and relatively low Young's modulus, which make them competitive to commercial protective TiN coatings [11].

In this article the synthesis of novel materials by spark plasma sintering and the possibility of subsequent using of compacts as a source for deposition of hard coatings with improved crack resistivity is presented. Till now there is no information about properties of $\mathrm{WB}_{2}$ SPSed compacts and deposited by magnetron sputtering method coatings doped by chromium, molybdenum, rhenium and zirconium.

The aim of this work is to investigate and compare the influence of $\mathrm{Re}, \mathrm{Mo}, \mathrm{Cr}$ and $\mathrm{Zr}$ dopants on the microstructure, mechanical properties and electrical conductivity of $\mathrm{WB}_{2}$ ceramics sintered by SPS method technique and explore the possibility of using them for deposition of functional coatings with magnetron sputtering method.

\section{Material and Methods}

\subsection{Spark Plasma Sintering}

Tungsten (purity: 99.9\%, APS: $25 \mu \mathrm{m}$ ), zirconium (purity: 99.8\%, APS: 250-350 $\mu \mathrm{m}$ ), molybdenum (purity: 99.9\%, APS: $<10 \mu \mathrm{m}$ ), rhenium (purity: 99.8\%, APS: $20 \mu \mathrm{m}$ ), chromium (purity: 99\%, APS: $<5 \mu \mathrm{m}$ ) and amorphous boron (purity: 95\%, APS: $1 \mu \mathrm{m}$ ) powders were mixed for 30 min using a Turbula T2F shaker-mixer (WAB, Muttenz, Switzerland) in the compositions presented in Table 1. The obtained powder mixtures were SPSed in vacuum using an HP D 25/3 (FCT Systeme, Frankenblick, Germany) furnace. The SPS process parameters are listed in Table 2. Samples with a diameter of $25.4 \mathrm{~mm}$ and thickness of $\approx 3.5 \mathrm{~mm}$ were produced.

Table 1. Weight content of tungsten, transition metals (chromium, molybdenum, rhenium, zirconium) and boron in W-TM-B powder mixtures.

\begin{tabular}{cccc}
\hline Material Composition & Tungsten, $(\mathbf{g})$ & TM, $(\mathbf{g})$ & Boron, $(\mathbf{g})$ \\
\hline $\mathrm{WB}_{2.5}$ & 12.202 & - & 1.795 \\
$\mathrm{~W}_{0.92} \mathrm{Cr}_{0.08} \mathrm{~B}_{2.5}$ & 11.817 & 0.291 & 1.890 \\
$\mathrm{~W}_{0.84} \mathrm{Cr}_{0.16} \mathrm{~B}_{2.5}$ & 11.389 & 0.614 & 1.995 \\
$\mathrm{~W}_{0.76} \mathrm{Cr}_{0.24} \mathrm{~B}_{2.5}$ & 10.911 & 0.975 & 2.112 \\
$\mathrm{~W}_{0.92} \mathrm{Mo}_{0.08} \mathrm{~B}_{2.5}$ & 11.613 & 0.527 & 1.857 \\
$\mathrm{~W}_{0.84} \mathrm{Mo}_{0.16} \mathrm{~B}_{2.5}$ & 10.982 & 1.092 & 1.924 \\
$\mathrm{~W}_{0.76} \mathrm{Mo}_{0.24} \mathrm{~B}_{2.5}$ & 10.305 & 1.698 & 1.995 \\
$\mathrm{~W}_{0.92} \operatorname{Re}_{0.08} \mathrm{~B}_{2.5}$ & 11.216 & 0.988 & 1.794 \\
$\mathrm{~W}_{0.84} \operatorname{Re}_{0.16} \mathrm{~B}_{2.5}$ & 10.232 & 1.974 & 1.792 \\
$\mathrm{~W}_{0.76} \operatorname{Re}_{0.24} \mathrm{~B}_{2.5}$ & 9.249 & 2.958 & 1.791 \\
$\mathrm{~W}_{0.92} \mathrm{Zr}_{0.08} \mathrm{~B}_{2.5}$ & 11.635 & 0.502 & 1.861 \\
$\mathrm{~W}_{0.84} \mathrm{Zr}_{0.16} \mathrm{~B}_{2.5}$ & 11.025 & 1.042 & 1.931 \\
$\mathrm{~W}_{0.76} \mathrm{Zr}_{0.24} \mathrm{~B}_{2.5}$ & 10.366 & 1.624 & 2.007 \\
\hline
\end{tabular}


Table 2. Spark plasma sintering process parameters of $\mathrm{W} / \mathrm{B}$ and $\mathrm{W} / \mathrm{Zr} / \mathrm{B}$ powder mixtures.

\begin{tabular}{ccccc}
\hline $\begin{array}{c}\text { Material } \\
\text { Composition }\end{array}$ & $\begin{array}{c}\text { Sintering } \\
\text { Temperature, }\end{array}{ }^{\circ} \mathrm{C}$ & $\begin{array}{c}\text { Heating Rate, } \\
{ }^{\circ} \mathbf{C} / \text { min }\end{array}$ & $\begin{array}{c}\text { Holding Time, } \\
\text { min }\end{array}$ & $\begin{array}{c}\text { Compacting } \\
\text { Pressure, MPa }\end{array}$ \\
\hline $\mathrm{W}_{1-\mathrm{x}} \mathrm{TM}_{\mathrm{x}} \mathrm{B}_{2.5}$ & 1800 & 400 & 24 & 50 \\
\hline
\end{tabular}

Optimal sintering parameters were selected on the basis of [9], where the influence of the holding time (2.5-30 $\mathrm{min})$, sintering temperature and compacting pressure on the densification behavior, microstructure evolution and development of the properties of $\mathrm{W}-\mathrm{Zr}-\mathrm{B}$ compounds were studied. An example of sintering curves (chromium) is presented in Figure 1. It is clearly seen that the densification process is complete and after $24 \mathrm{~min}$ the displacement of punch is nearly constant.

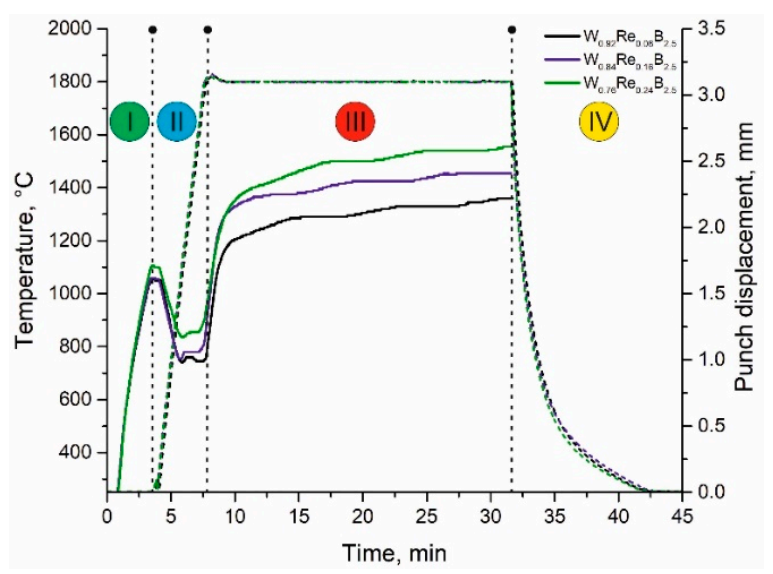

Figure 1. Sintering curves of $\mathrm{W}_{1-\mathrm{x}} \mathrm{Cr}_{\mathrm{x}} \mathrm{B}_{2.5}(0<\mathrm{x} \leq 0.24)$ samples spark plasma sintered for $24 \mathrm{~min}$. Dotted lines are temporal distribution of sintering temperature.

\subsection{Radio Frequency Magnetron Sputtering (RF-MS)}

W-TM-B (where TM = Cr, Mo, Re, Zr) films were deposited by RF magnetron sputtering on $\mathrm{Si}(100)$ plates. The substrates were cleaned with subsequent rinses in acetone, alcohol and deionized water. Each of the substrates was mounted on a rotating substrate holder and heated to $520^{\circ} \mathrm{C}$. Heating was performed for better layer-to-substrate adhesion [19].

The deposition was performed in a vacuum chamber pumped (PREVAC, Rogów, Poland) to residual pressure of $10^{-3} \mathrm{~Pa}$ and then filled with argon to a working pressure of $0.9 \mathrm{~Pa}$. The argon flow was $19 \mathrm{~mL} / \mathrm{min}$ and it was adjusted with a mass flow controller. For deposition the $\mathrm{W}_{0.76} \mathrm{TM}_{0.24} \mathrm{~B}_{2.5}$ targets were chosen because of the best properties of coatings obtained from target with titanium dopant [6]. The water-cooled W-TM-B targets were mounted in the 1" magnetron source (Kurt J. Lesker TORUS Magnetron Sputtering Cathode, Jefferson Hills, PA, USA) and positioned at a distance of $40 \mathrm{~mm}$ from the substrate. The RF sputtering power was $60 \mathrm{~W}$. The bias potential on the substrate was floating. Pre-sputtering of the target was carried out for $5 \mathrm{~min}$ prior to each deposition. Then, the substrate holder was positioned next to the magnetron. The deposition time was $120 \mathrm{~min}$. The deposition conditions were chosen due to the best mechanical and tribological properties of films presented in [6].

\subsection{Characterization}

The density of the SPSed samples was measured using the Archimedes method according to the ISO 18754: 2013 standard using an EX 2225DM (Ohaus, Parsippany, NJ, USA) laboratory scale with a resolution of $0.00001 \mathrm{~g}$. The phase composition of the samples was examined by X-ray diffraction (XRD) with a D8 Discover (Bruker, Billerica, MA, USA) using $\mathrm{CuK}_{\alpha}$ radiation $(\lambda=1.5418 \AA)$. Microscopic observations of the microstructure and elemental microanalysis to study the elemental distribution of tungsten, zirconium 
and boron in the investigated samples were performed using a JSM6010PLUS/LV (JEOL, Tokyo, Japan) scanning electron microscope (SEM) equipped with an energy-dispersive $\mathrm{X}$-ray spectroscope (EDS). Accelerating voltage $10 \mathrm{kV}$ was used. For sintered compacts, Vickers hardness measurements were performed using Wilson VH1102 microhardness tester (Buehler, Lake Bluff, IL, USA). Load of 200 gf was used to measure hardness of targets and loads of 10, 25, $50 \mathrm{~g}$ were used to measure hardness of deposited coatings; 10 indentations on each sample were performed. For lower loads, a laser confocal microscope VK-X100 (Keyence, Osaka, Japan) was used to measure the indents. Vickers hardness was recalculated to account the influence of substrate by using Equation (1) [20].

$$
H_{c}=H_{s}+\left[2 C \frac{t}{D}-C^{2}\left(\frac{t}{D}\right)^{2}\right]\left(H_{f}-H_{s}\right)
$$

where: $H_{c}$ is the measured Vickers hardness of deposited composite bilayer, $H_{S}$ is the hardness of silicon substrate, $C=2 \sin ^{2}(f / 2), f$ is the angle of the tip sides with the surface ( $f=22^{\circ}$ for Vickers intender), $t$ is the film thickness, $D$ is the indentation depth (basing on indent diameter and ideal geometry of indenter) and $H_{f}$ is the hardness of the film. Palmqvist method [21] was used to analyze changes in fracture toughness $\left(\mathrm{K}_{1 \mathrm{c}}\right)$. For each coating, based on a group of 10 indentations, the value of crack $l$, from the corner of the indent to end of crack, was determined. Equation (2) was used to evaluate the fracture toughness of deposited coatings.

$$
K_{I C}=0.0028 \times \sqrt{H V} \times \sqrt{\frac{P}{T}}
$$

where: $\mathrm{K}_{1 \mathrm{c}}$ is fracture toughness (MPa m ${ }^{1 / 2}$ ), $\mathrm{HV}$ is Vickers hardness in $\mathrm{N} / \mathrm{mm}^{2}$ (or MPa), $P$ is the load $(\mathrm{N})$ and $T$ is total crack length $(\mathrm{mm})$ measured from each corner of the indent $(4 \times l)$. The electrical conductivity was measured according to the ASTM E1004 standard using a Sigma Check (Ether NDE, St Albans, UK) eddy current conductivity meter.

\section{Results and Discussion}

\subsection{Targets}

\subsubsection{Density}

The densification behavior of the powder mixtures during the SPS process (see Figure 1) was analyzed based on the upper punch displacement registered with resolution of $0.01 \mathrm{~mm}$ during the compacting (I), heating (II), holding (III) and cooling (IV) stage. Regardless of the dopant, the profile of the sintering curves is similar. In the stage (I), when the powder mixtures are compacted, this punch moved by $\approx 1.6-1.7 \mathrm{~mm}$ in positive (+) direction. At the end of the compacting stage, when the compacting pressure of $50 \mathrm{MPa}$ was reached, the powder mixtures were heated from the ambient temperature to $1800^{\circ} \mathrm{C}$ with heating rate of $400{ }^{\circ} \mathrm{C} / \mathrm{min}$ (stage (II)). At the beginning of this stage, due to the thermal expansion of the graphite tool setup, punch displacement in negative (-) direction is clearly seen. As the temperature increases, this effect is compensated by the further densification of the powder mixtures. When sintering temperature of $1800{ }^{\circ} \mathrm{C}$ is reached, further densification is also clearly seen in the upper punch displacement in positive direction. In Figure 1 it is clearly seen that sintering for $2.5 \mathrm{~min}$ is not enough to complete the densification process and sintered compacts with open porosity were obtained. The minimum holding time required to obtained near full dense sintered compacts is $8 \mathrm{~min}$ and a couple of seconds before this time the plateau of the sintering curves is clearly seen. This means that sintering is completed under certain conditions. Nevertheless, a further increase in the holding time (up to $15.5 \mathrm{~min}$ ) resulted in further upper punch movement. This is related to the reactive sintering and creation of diborides from pure elements resulted in an increase in the density of the sintered body and finished between 14 and $15 \mathrm{~min}$ without any further densification (plateau of curves). Increasing the holding time to $30 \mathrm{~min}$ does 
not cause significant changes in densification of the samples. The dependence of density on composition change is presented in Figure 2.

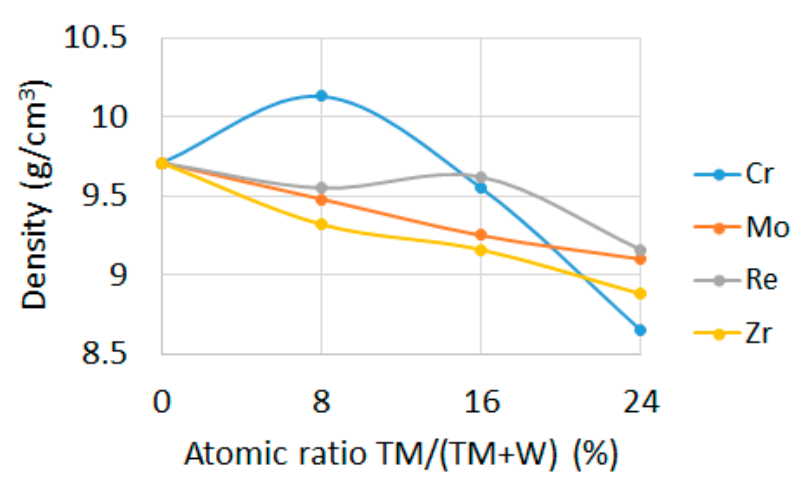

Figure 2. Changes in the density of the SPSed samples in function of amount and type of admixture $\mathrm{TM}$ (where $\mathrm{TM}=\mathrm{Cr}, \mathrm{Mo}, \mathrm{Re}, \mathrm{Zr}$ ).

It is clearly seen from Figure 2 that as the amount of dopant increased, the density decreased and this is related to the lower atomic mass of dopant and also phase transformation occurring during the holding time from pure elements to $(\mathrm{W}, \mathrm{TM}) \mathrm{B}_{2}$ phase, whose density is lower than the $\mathrm{WB}_{2}$ phase. In turn, the density of the $\mathrm{W}_{0.92} \mathrm{Cr}_{0.08} \mathrm{~B}_{2.5}$ increases in comparison to $\mathrm{WB}_{2.5}$. This may be connected with creation of solid solution of $\mathrm{WB}_{2}$ with $\mathrm{Cr}$ where chromium takes not occupied by tungsten atoms positions in hexagonal structure of $\mathrm{WB}_{2}$. For higher concentrations, when the solubility limit is reached, the $\mathrm{CrB}_{2}$ phase begins to precipitate. Chromium diboride is much softer than the $\mathrm{WB}_{2}$ phase and has a much lower density (5.21 and $12.76 \mathrm{~g} / \mathrm{cm}^{3}$ [22] respectively).

\subsubsection{Microstructure}

Figure 3 shows SEM micrographs and chemical analysis of $(\mathrm{W}, \mathrm{TM}) \mathrm{B}_{2.5}$ sintered compacts surface alloyed with 8 at.\% and 24 at.\% of TM, where TM: Cr (Figure 3a), Mo (Figure 3b), Re (Figure 3c) and $\mathrm{Zr}$ (Figure 3d). In the left figures results of 8 at.\% of addition were shown, at right -24 at.\% respectively. In the middle position of Figure 3 an EDS analysis of tungsten and TM content in 24 at.\% samples is presented. The rectangles with elements symbols point to the zones with maximal content of element. As it can be seen, the micrographs were done with different magnification. It is connected with different microstructure of compacts. In the case of chromium (Figure 3a), the samples are the most homogenous. For 8 at.\% $\mathrm{Cr}$ the places with a predominance of chromium are not observed. The solubility limit is not reached and the chromium atoms are located in the crystal lattice of $W_{2}$ which is supported by XRD spectra of this sample (Figure 4a). The increase of chromium content causes the $\mathrm{CrB}_{2}$ to appear and can be observed in micrographs in the form of grains with irregular shapes. Similar results are observed in the case of molybdenum (Figure $3 b$ ) where grains of $\mathrm{MoB}_{2}$ are observed. Addition of rhenium caused $\mathrm{ReB}_{2}$ to be observed also for lower content of this element. The zones with rhenium diboride $\left(\mathrm{ReB}_{2}\right)$ are greater than for $\mathrm{Cr}$ and Mo. However, it is hard to indicate zones with a predominance of Re using SEM with backscattered electron (BSE) mode and EDS because the atomic mases of tungsten and rhenium are similar, 183.85 and $186.20 \mathrm{u}$ respectively, and the contrast between both phases is very low. Zirconium is two times lighter and it is easy to see that it possesses the greatest grains among studied elements. It can be explained by the size of the used powders. The dimension of zirconium powders is about ten times greater than the size of tungsten powders. In this case the zirconium diboride is created mainly on the grain boundary (Figure 3d). 
(a)

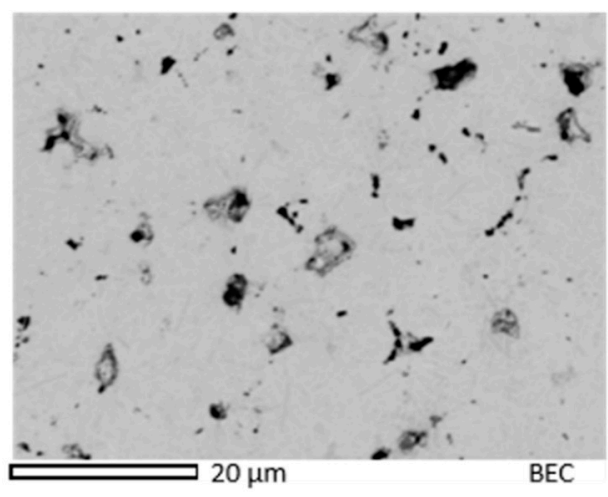

(b)

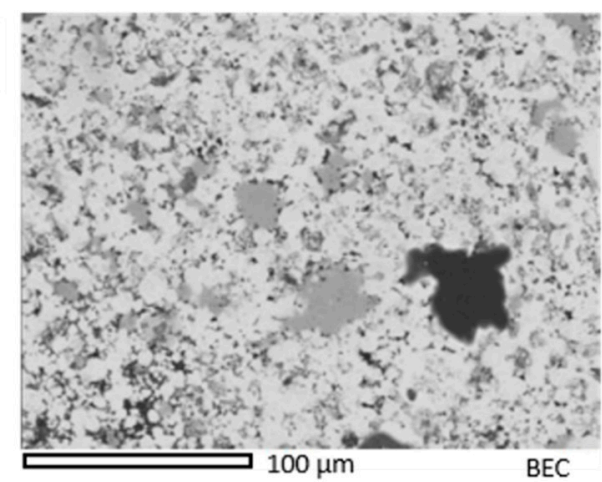

(c)

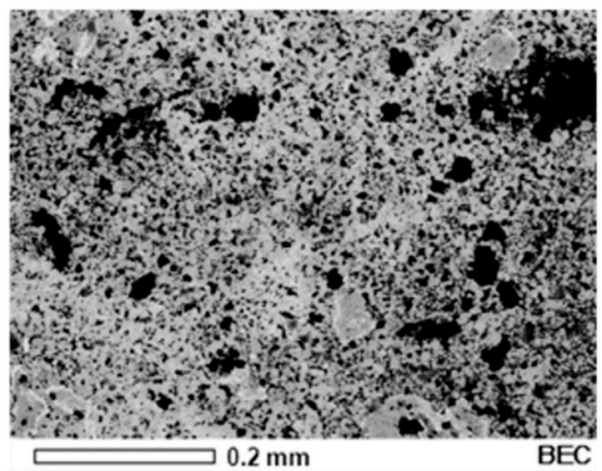

(d)

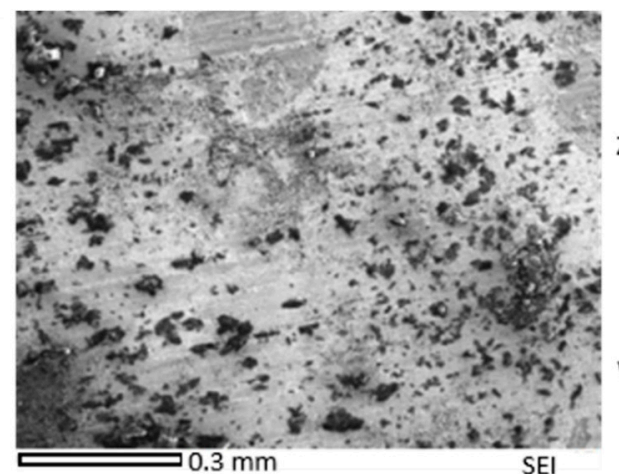

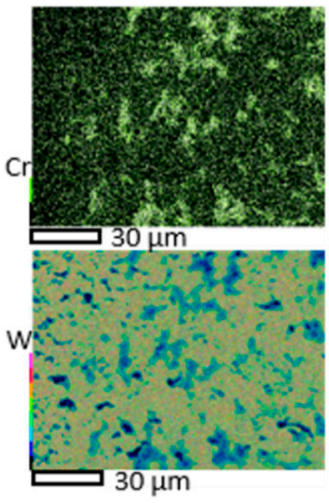
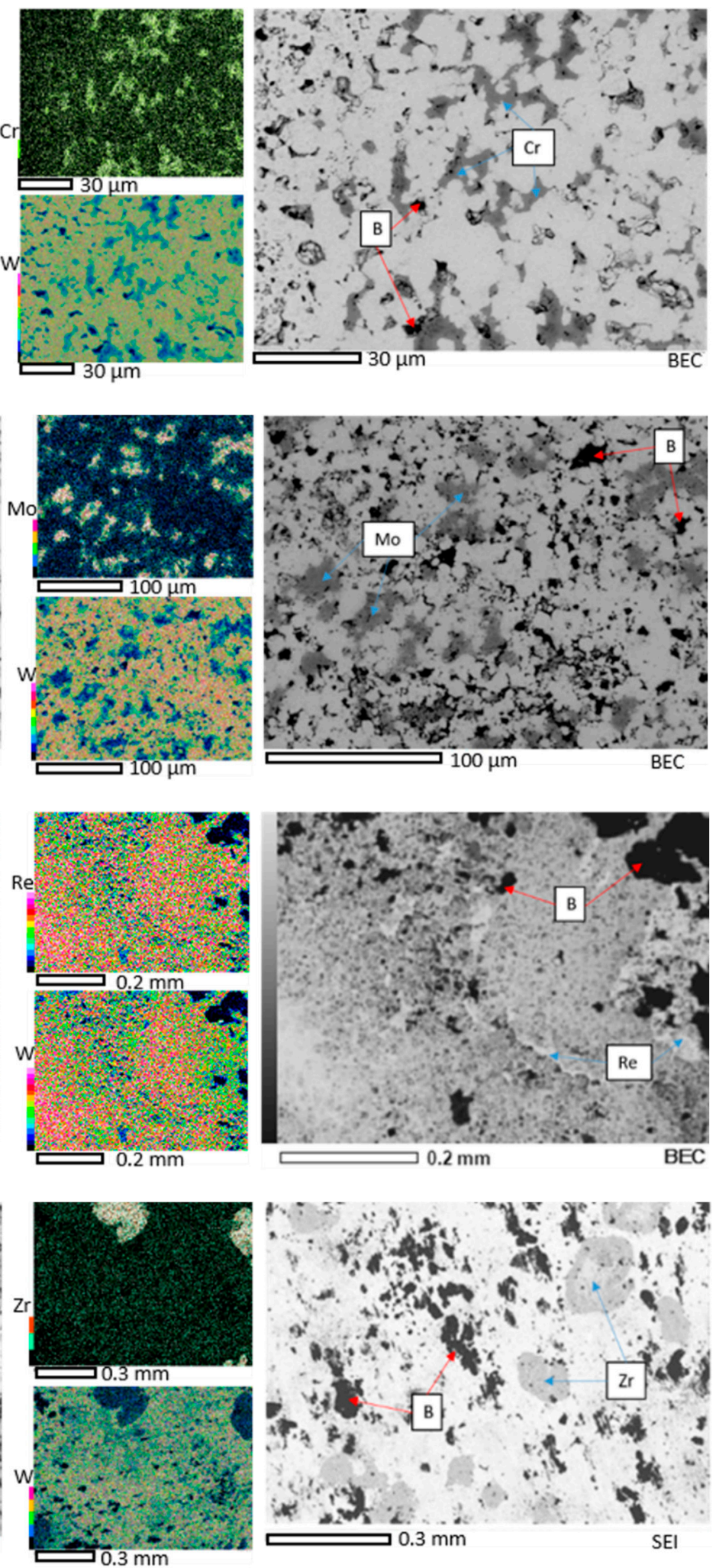

Figure 3. SEM micrographs and chemical analysis of $(\mathrm{W}, \mathrm{TM}) \mathrm{B}_{2.5}$ sintered compact surface alloyed with 8 at. $\%$ and 24 at. $\%$ TM, where TM: (a) Cr, (b) Mo, (c) Re, (d) Zr. Left figures show results of 8 at.\% of addition, right 24 at.\% respectively and middle is an EDS analysis of W and TM content in 24 at.\% samples. Only one element is presented in each picture. Black colour means $0 \%$ at. and pink $100 \%$ at. respectively. 
(a)

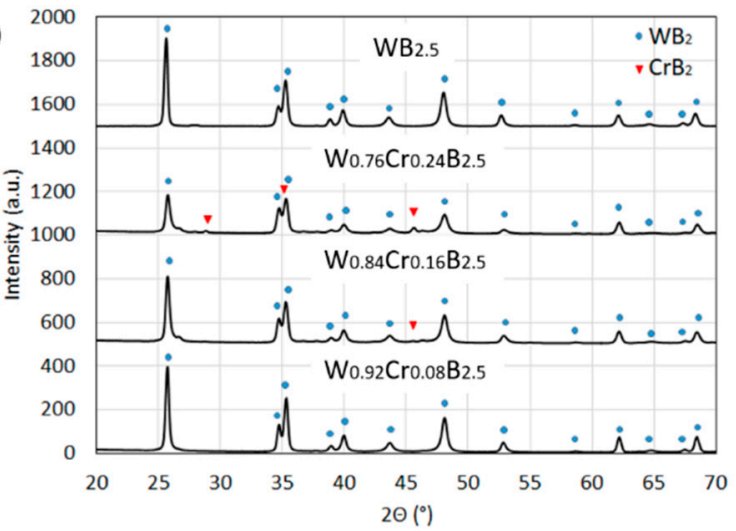

(c)



(b)

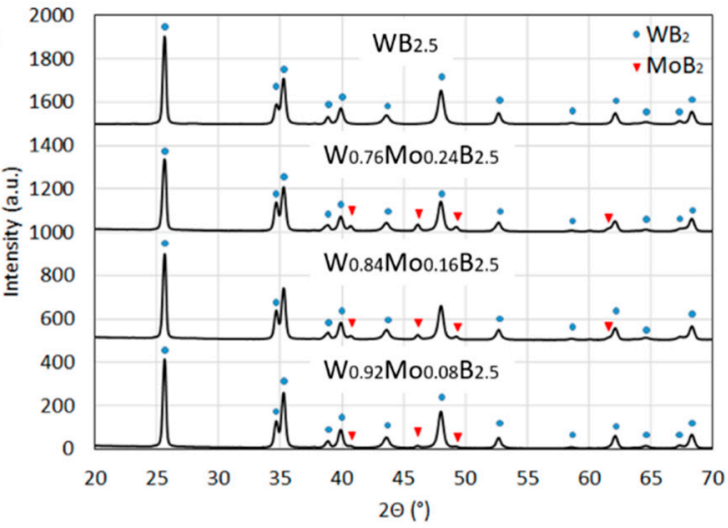

(d)

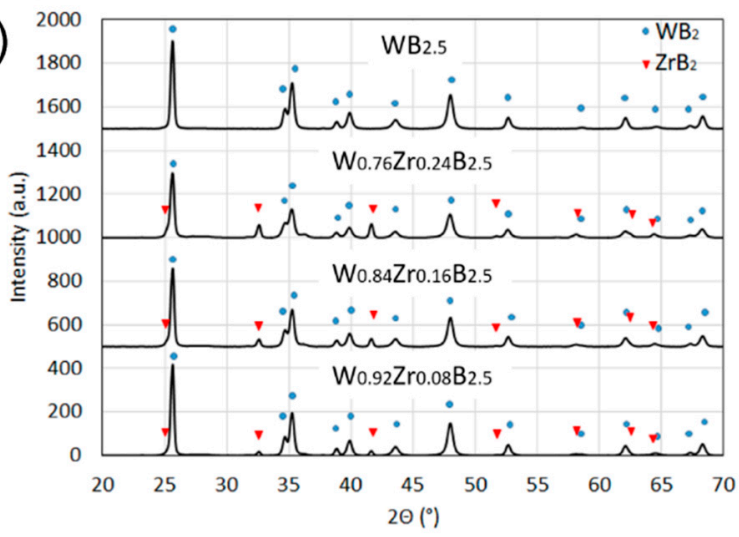

Figure 4. XRD spectra of phase composition of samples $\mathrm{W}_{1-\mathrm{x}} \mathrm{TM}_{\mathrm{x}} \mathrm{B}_{2.5}$ with molar ratio of $\mathrm{x}=\mathrm{TM} /(\mathrm{TM}+\mathrm{W})$ where $\mathrm{x}=0,8$, 16 and 24 at.\% and TM: (a) Cr, (b) Mo, (c) Re, (d) Zr.

The diborides formation can be proved by using the XRD technique. Figure 4a shows the XRD patterns of $\mathrm{W}_{\mathrm{x}-1} \mathrm{Cr}_{\mathrm{X}} \mathrm{B}_{2}$ compound. These spectra show that the solubility of $\mathrm{Cr}$ in hexagonal $\mathrm{P}_{3} / \mathrm{mmc} \mathrm{WB}_{2}$ (the upper spectra) is greater than 16 at.\% and above $\mathrm{CrB}_{2}$ appears as a second phase. An atomic radius of chromium is lower than the other used TM metals, and in agreement with this fact, the solubility of chromium in $\mathrm{WB}_{2}$ appears to be the highest. The XRD spectra of Mo, Re and $\mathrm{Zr}$ added compounds are shown in Figure $4 \mathrm{~b}-\mathrm{d}$ respectively. The solubility of these elements in $\mathrm{WB}_{2}$ is below 8 at.\%. At and above 8 at.\% TM addition, trigonal (R3m) $\mathrm{MoB}_{2}$, hexagonal $\mathrm{P}_{3} / \mathrm{mmc} \mathrm{ReB}_{2}$ and hexagonal $\mathrm{P} 6 / \mathrm{mmm} \mathrm{ZrB}$ starts to show up as an additional phase. The lattice parameters of the $\mathrm{WB}_{2}$ solid solutions are $\mathrm{a}=2.985$ and $\mathrm{c}=13.900 \AA$, respectively. It can be noted that the addition of small amounts of $\mathrm{Cr}, \mathrm{Mo}, \mathrm{Re}$ and $\mathrm{Zr}$ does not change the lattice parameters of $\mathrm{WB}_{2}$. Only a small shift of the strongest peak (0 004$)$ to higher angles is observed $\left(0.08^{\circ}\right.$, Figure 3$)$ and may result from the stresses caused by the filling vacancies by atoms with different radii.

The microstructure of obtained compacts strongly depends on crystal structure of synthetized borides and also diameter of used powders. The structure of tungsten diboride allows it to accommodate metal atoms in vacancies in addition to ordinary substitution of metal (tungsten) positions, which enables alloys with other transition metals ( $\mathrm{Zr}, \mathrm{Mo}$ and $\mathrm{Cr}$ ) to have enhanced mechanical properties (hardness), oxidation resistance and electrical conductivity [5]. Therefore, in addition to accommodating the metals in the voids inside the structure (as well as substitute in tungsten positions in the case of $\mathrm{W}_{1-x} \mathrm{Mo}_{\mathrm{x}} \mathrm{B}_{2.5}$ ) $\mathrm{WB}_{2}$ can also form a traditional solid solution, and therefore, the Hume-Rothery rules (atomic radii difference, similarity of crystal structure, oxidation states and electronegativity) are fully applicable to these cases [23]. Such situation can be observed for $\mathrm{Mo}, \mathrm{Cr}$ and $\mathrm{Zr}$ where the most stable hexagonal structure $\mathrm{P} 6 / \mathrm{mmm}$ is created during reactive sintering. For $\mathrm{ReB}_{2}$, the phase $\mathrm{P}_{3} / \mathrm{mmc}$ is formed at all concentrations of rhenium. In this case, rhenium forms a very favorable, stable phase and does not readily alloy with $\mathrm{WB}_{2}$. In result the 
spectra of this phase have higher intensity than other dopants (Figure 4c). In the case of zirconium, the diameter of used powders is crucial. The diameter of used zirconium powder is above ten times higher than tungsten. During sintering only surface of zirconium particles was reacted with boron and zirconium diboride was created (Figure 3d). Similar observation was done by Garbiec et al. [9]. As it will be shown in the next paragraphs, it highly influences hardness and electrical conductivity of compacts.

\subsubsection{Hardness}

In Figure 5 the results of Vickers hardness are presented. The increase of hardness can be observed with an increase in the $\mathrm{Cr}, \mathrm{Mo}$, Re and $\mathrm{Zr}$ content. At low contents (below 8 at.\%), by sitting at the positions of missing tungsten atoms, these elements could induce either tungsten vacancy at the $\mathrm{WB}_{2}$ structure. It may cause the defect structure of material and may be responsible for the hardening trends observed for the solid solutions. For higher concentrations, XRD results (Figure 3) indicate the possibility of grain boundary strengthening mechanisms outside the solubility limits of three elements (Mo, Re and $\mathrm{Zr}$ ). The greatest increase of hardness is observed for Re. It can be explained by the greatest hardness of $\mathrm{ReB}_{2}(\mathrm{HV}=30.40-48.0 \mathrm{GPa}[12,22])$ among all diborides. With the increase of content of rhenium, the amount of rhenium diboride grows and can cause dispersion hardening. Due to the fact that the differences in the microhardness of $\mathrm{ZrB}_{2}$ [24] or $\mathrm{MoB}_{2}$ [10] and $\mathrm{WB}_{2}$ [22] are insignificant, at lower contents, i.e., 0 and 16 at.\% the hardness practically does not change and is about $23 \pm 1 \mathrm{GPa}$. In the case of zirconium, according to the phase diagram of the $\mathrm{W}_{2} \mathrm{~B}_{5}-\mathrm{ZrB}_{2}$ pseudobinary system [25], a further increase in the amount of dopant results in achieving the composition with the lowest melting point $\left(2180 \pm 30{ }^{\circ} \mathrm{C}\right.$ for the eutectic composition of $80 \mathrm{~mol} \% \mathrm{~W}_{2} \mathrm{~B}_{5}+20 \mathrm{~mol} \%$ $\mathrm{ZrB}_{2}$ ). This phenomenon promotes greater consolidation of the material and thus also an increase in hardness. Moreover, on the basis of the analysis of the microstructure of the samples with the higher zirconium content (Figure 3d), both the unbound boron and $\mathrm{ZrB}_{2}$ grains are smaller and more evenly distributed, which promotes dispersion strengthening. A similar relationship was observed by Hirota et al. [26] when $\mathrm{ZrB}_{2}$ was doped with small amounts of tungsten. For monolithic $\mathrm{Zr}_{1-\mathrm{x}} \mathrm{W}_{\mathrm{x}} \mathrm{B}_{2}(0<\mathrm{x} \leq 0.12)$, W-doped $\mathrm{ZrB}_{2}$ solid solutions with a lower hardness were formed and the hardness grew and stabilized for composites consisting of $\mathrm{ZrB}_{2}$ solid solutions and $\mathrm{WB}_{2}$ when $\mathrm{x}>0.12$ due to the formation of solid solution, homogeneously dispersed needle-like $\mathrm{WB}_{2}$ particles [26]. An inverse relationship for hardness can be observed for the higher chromium content, where the hardness decreases with an increase in the chromium content. In this case chromium diboride is the softest material among investigated borides and increase of amount of $\mathrm{CrB}_{2}$ causes the decrease in hardness.

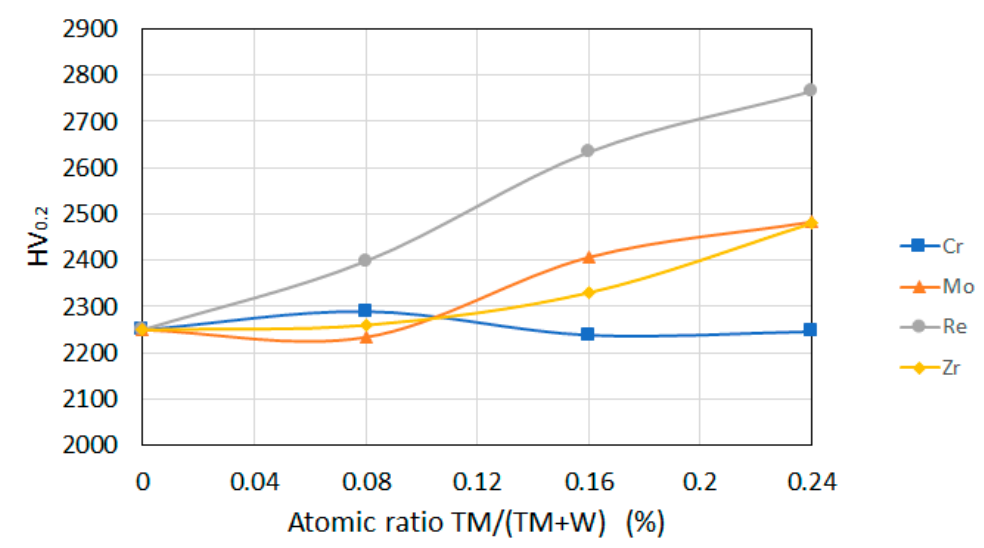

Figure 5. Hardness of $\mathrm{W}_{\mathrm{x}} \mathrm{TM}_{\mathrm{x}-1} \mathrm{~B}_{2.5},(0<\mathrm{x} \leq 0.24 \mathrm{TM}=\mathrm{Cr}, \mathrm{Mo}, \mathrm{Re}, \mathrm{Zr})$; specimens spark plasma sintered at holding times $24 \mathrm{~min}$. 


\subsubsection{Electrical Conductivity}

The electrical conductivity of the $\mathrm{W}_{\mathrm{x}} \mathrm{TM}_{\mathrm{x}-1} \mathrm{~B}_{2.5},(0<\mathrm{x} \leq 0.24 \mathrm{TM}=\mathrm{Cr}, \mathrm{Mo}, \mathrm{Re}$, $\mathrm{Zr}$ ) samples is shown in Figure 6. It is clearly seen that the electrical conductivity of the samples with zirconium content is more or less two times higher than the samples without admixture and increases at ambient temperature with an increasing zirconium content up to $3.961 \times 10^{6} \mathrm{~S} / \mathrm{m}$. In the case of molybdenum and rhenium the electrical conductivity is almost constant with increasing content of dopant. This is a result of similar conductivity of $\mathrm{MoB}_{2}$ and $\mathrm{ReB}_{2}$ to $\mathrm{WB}_{2}$ and better electrical conductivity of zirconium diboride, respectively. Exemplary values of electrical conductivities for clean diborides are presented in Table 3.

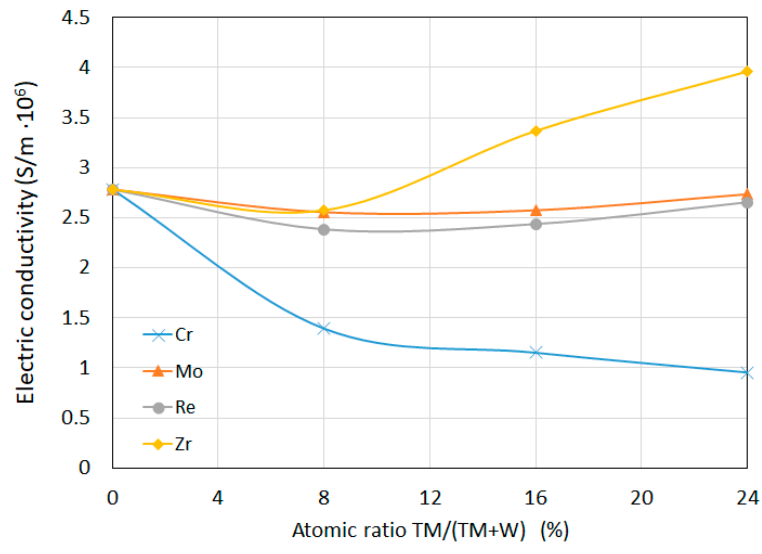

Figure 6. Electrical conductivity of $\mathrm{W}_{\mathrm{x}} \mathrm{TM}_{\mathrm{x}-1} \mathrm{~B}_{2.5},(0<\mathrm{x} \leq 0.24 \mathrm{TM}=\mathrm{Cr}$, Mo, Re, Zr); samples spark plasma sintered at holding time $24 \mathrm{~min}$.

Table 3. Electrical conductivity of $\mathrm{TM}(\mathrm{TM}=\mathrm{W}, \mathrm{Cr}, \mathrm{Mo}, \mathrm{Re}, \mathrm{Zr})$ diborides and tungsten carbide.

\begin{tabular}{ccccccc}
\hline Boride & $\mathbf{W B}_{\mathbf{2}}$ & $\mathbf{C r B}_{\mathbf{2}}$ & $\mathbf{M o B}_{\mathbf{2}}$ & $\mathbf{R e B}_{\mathbf{2}}$ & $\mathbf{Z r B}_{\mathbf{2}}$ & $\mathbf{W C} \mathbf{C o}$ \\
\hline Electrical conductivity & $1.1-4.5 \times 10^{6}$ & $0.95-1.42 \times 10^{6}$ & $7.8 \times 10^{6}$ & $2.45 \times 10^{6}$ & $10.9 \times 10^{6}$ & $4.76 \times 10^{6}$ \\
$(\mathrm{~S} / \mathrm{m})$ & {$[27]$} & {$[28]$} & {$[10]$} & {$[29]$} & {$[30]$} & {$[31]$} \\
\hline
\end{tabular}

Furthermore, the increased content of chromium decreased the electrical conductivity. For these materials, the addition of chromium reduces the electrical conductivity of the sintered compacts from $1.393 \times 10^{6}$ to $0.954 \times 10^{6} \mathrm{~S} / \mathrm{m}$. It should be noted that the electrical conductivity of $\mathrm{WB}_{2.5}$ alloyed with Mo or $\operatorname{Re}\left(\approx 2.5 \times 10^{6} \mathrm{~S} / \mathrm{m}\right)$ is greater than the electrical conductivity of 304 stainless steel $\left(1.45 \times 10^{6} \mathrm{~S} / \mathrm{m}\right)$ and in the case of 24 at.\% zirconium is similar to the electrical conductivity of WC-Co cemented carbides $\left(4.76 \times 10^{6} \mathrm{~S} / \mathrm{m}\right)$ [31].

\subsection{Coatings}

Targets with an admixture of 24 at.\%. TM were selected to show the differences in the properties of the deposited layers. After $2 \mathrm{~h}$ of deposition all the coatings were smooth with a roughness below $22 \pm 5 \mathrm{~nm}$. No delamination was observed. An exemplary SEM micrograph for rhenium is presented in Figure 7a. Thickness of coatings differ from each other (Table 2). The greatest thickness is found in films with rhenium addition $(3.18 \mu \mathrm{m})$ and the thickest coatings are for chromium $(1.67 \mu \mathrm{m})$. As can be easily seen, the thickness of the layers decreases with molecular weight of the dopant. Rhenium has the greatest mass $(186 \mathrm{u})$, comparable to tungsten $(184 \mathrm{u})$, and chromium the lowest $(52 \mathrm{u})$. It can influence dynamics of plasma during magnetron sputtering. The SEM-EDS analysis indicates that chemical elements of $\mathrm{W}_{\mathrm{x}} \mathrm{TM}_{1-\mathrm{x}} \mathrm{B}_{\mathrm{y}}$ coatings were homogeneously distributed (see Figure $7 \mathrm{~b}-\mathrm{e}$ ). 
(a)

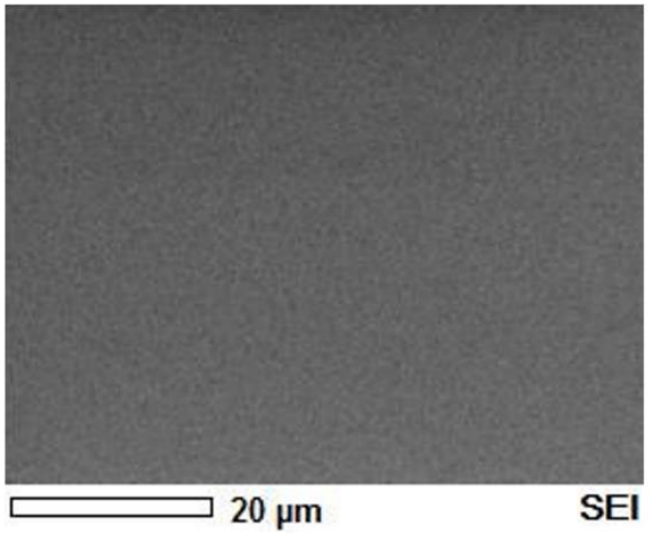

(b)

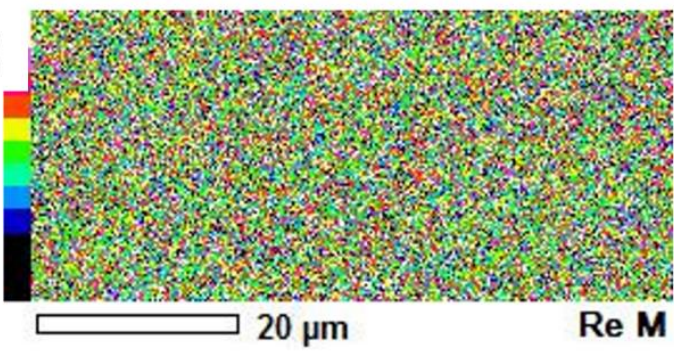

(c)

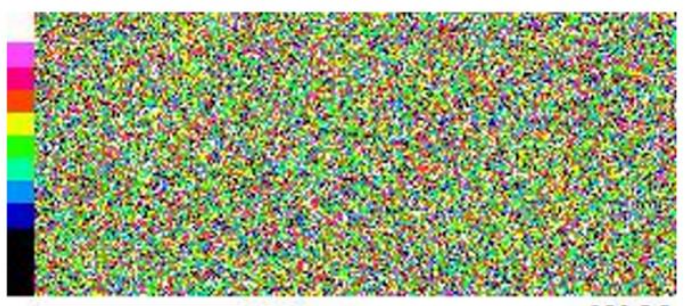

$20 \mu \mathrm{m}$

W M

(d)

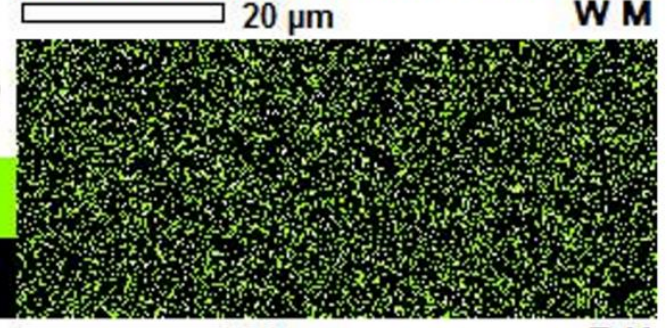

$20 \mu \mathrm{m}$

B K

(e)

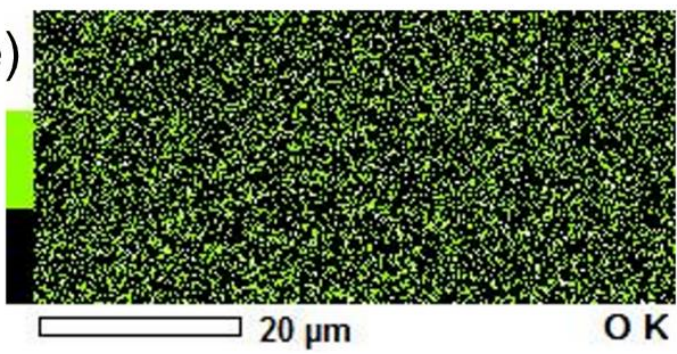

Figure 7. (a) SEM micrograph, EDS maps of elements: (b) Re, (c) W, (d) B, (e) O in the coating deposited from the $\mathrm{W}_{0.76} \operatorname{Re}_{0.24} \mathrm{~B}_{0.25}$ target.

The quantitative analysis of chemical composition showed that stoichiometry of target is not preserved (Table 2). In all cases the TM and boron content dropped in the comparison to target composition. The decrease in TM content, as in the case of boron, is predicted to be due to scattering of the TM atoms on the tungsten atoms in the plasma plume during deposition. In addition, resputtering of atoms from surface deposited coatings is also possible. A decrease in light elements was already observed in References [18,32]. The boron content $\mathrm{B} /(\mathrm{Zr}+\mathrm{W})$ is in the range of 1.54-2.06 (see Table 2) which means boron decrease of 38.4-17.7\% respectively compared to the target composition. In the case of transition metals losses are much smaller, which can be explained by their greater mass in relation to boron. In all coatings the presence of oxygen was detected. The lower content of oxygen was in films with chromium admixture (2.16 at.\%) and the higher was for rhenium (5.24 at.\%) respectively (Table 4$)$.

Table 4. Chemical composition and thickness of deposited coatings $W_{1-x} \mathrm{TM}_{\mathrm{x}} \mathrm{B}_{\mathrm{y}}$ alloyed with $\mathrm{TM}$ $(\mathrm{TM}=\mathrm{Cr}, \mathrm{Mo}, \mathrm{Re}, \mathrm{Zr})$.

\begin{tabular}{ccccc}
\hline $\mathbf{T M}$ & $\mathbf{x}=\mathbf{T M} / \mathbf{T M}+\mathbf{W})$ & $\mathbf{y}=\mathbf{B} /(\mathbf{T M}+\mathbf{W})$ & at. $\% \mathbf{O}(\%)$ & Thickness $(\mu \mathbf{m})$ \\
\hline $\mathrm{Cr}$ & 0.213 & 1.698 & 2.16 & 2.31 \\
$\mathrm{Mo}$ & 0.217 & 2.057 & 3.70 & 2.34 \\
$\operatorname{Re}$ & 0.185 & 1.540 & 5.24 & 3.18 \\
$\mathrm{Zr}$ & 0.202 & 1.919 & 3.42 & 2.25 \\
\hline
\end{tabular}

In Figure 8, XRD spectra of phase composition in deposited coatings is presented. Only spectra were recorded in the range of $24^{\circ}-31^{\circ}$. XRD spectra of phase composition corresponds to the phase $\mathrm{WB}_{\mathrm{y}}$ [18]. The comparison of XRD pattern of targets (Figure 4) and deposited coatings indicates the change of crystal structure of $\mathrm{WB}_{2}$ from softer $\omega-\mathrm{WB}_{2}$ $\left(\mathrm{P}_{3} / \mathrm{mmc}\right)$ to harder $\alpha-\mathrm{WB}_{2}(\mathrm{P} 6 / \mathrm{mmm})$. Regarding the synthesis via physical vapor 
deposition, it is a well-known fact that metastable structures can be captured via this synthesis route [5]. Admixture of transition metals does not cause of appearance of new phases of TM borides. XRD spectra of W-TM- $\mathrm{B}_{\mathrm{y}}$ do not differ significantly from $\mathrm{WB}_{\mathrm{y}}$. However, careful analysis of the plot shows that depending on the used element, the peak positions are shifted. The black arrows in Figure 8 denote the direction of shift of $\left(\begin{array}{llll}0 & 0 & 0 & 1\end{array}\right)$ peak position. Only alloying with zirconium is significant and changes the direction of sift. Comparing the radii of the used elements with radii of tungsten (1.394 $\AA$ [33]), it can be observed that zirconium has a much larger radius than the other elements $(\mathrm{Zr}-1.597 \AA$; $\mathrm{Cr}-1.357 \AA ; \mathrm{Mo}-1.386 \AA$; Re-1.373 $\AA$ [33]). The transition metal atoms take the places of tungsten in the crystal lattice, thus creating a solid solution with $\mathrm{WB}_{2}$. Since zirconium possesses the radius larger than tungsten only, this makes the unit cell larger and causes the shift to lower angles. Detailed deconvolution of XRD spectra leads to the determination of cell parameters. The $\mathrm{WB}_{2}$ phase has lattice parameters $\mathrm{a}=2.96 \AA$ and $\mathrm{c}=3.089 \AA$ and addition of zirconium increases them to $\mathrm{a}=3.028 \AA$ and $\mathrm{c}=3.192 \AA$ respectively.



Figure 8. XRD spectra of phase composition of $\mathrm{WB}_{\mathrm{y}}$ [18] and $\mathrm{W}-\mathrm{TM}-\mathrm{B}_{\mathrm{y}}$ coatings deposited from targets alloyed with 24 at.\% TM $(\mathrm{TM}=\mathrm{Cr}, \mathrm{Mo}, \mathrm{Re}, \mathrm{Zr})$. Black arrows denote direction of shift of $\left(\begin{array}{llll}0 & 0 & 0 & 1\end{array}\right)$ peak position.

All deposited coatings are very hard and the results of hardness measurement under load 10, 25 and $50 \mathrm{~g}$ are presented in Table 5. Film alloyed with $\mathrm{Cr}$ possesses the greatest hardness; after recalculation that takes into account coatings' thickness (Equation (1)) and conversion to SI unit, it is $50.4 \pm 4.7 \mathrm{GPa}$ (at $98 \mathrm{mN}$ ). In the case of $\mathrm{Mo}, \mathrm{Zr}$ and $\mathrm{Re}$ the hardness is lower and is $45.4 \pm 6.7,43.9 \pm 3.3$ and $32.6 \pm 6.4 \mathrm{GPa}$ respectively. These values are lower than hardness of unalloyed $\mathrm{WB}_{2}$ presented in literature $(\mathrm{H}=46 \pm 2 \mathrm{GPa}$ [18] $)$ However, it should be noted that hardness results presented by Psiuk et al. [18] were measured by nanoindentation method under load of $3 \mathrm{mN}$. The lowest hardness, when rhenium is added, can be explained by the degree of crystallization conducted from XRD spectra. In this case the intensity of $\left(\begin{array}{llll}0 & 0 & 0 & 1\end{array}\right)$ peak (Figure 8) is also the lowest, which suggests that coatings are more amorphous. Additionally, decrease in boron content and creation of vacancies can influence this mechanical property.

Table 5. Measured and recalculated hardness (Equation (1)) of deposited coatings.

\begin{tabular}{ccccccc}
\hline TM & $\mathbf{H V}_{\mathbf{0 . 0 1}}$ & $\begin{array}{c}\mathbf{H V}_{\mathbf{0 . 0 1}} \\
\text { (Recalculated) }\end{array}$ & $\mathbf{H V}_{\mathbf{0 . 0 2 5}}$ & $\begin{array}{c}\mathbf{H V}_{\mathbf{0 . 0 2 5}} \\
\text { (Recalculated) }\end{array}$ & $\mathbf{H V}_{\mathbf{0 . 0 5}}$ & $\begin{array}{c}\mathbf{H V}_{\mathbf{0 . 0 5}} \\
\text { (Recalculated) }\end{array}$ \\
\hline $\mathrm{Cr}$ & $3610 \pm 390$ & $5140 \pm 480$ & $2760 \pm 190$ & $5570 \pm 390$ & $2140 \pm 120$ & $5490 \pm 380$ \\
$\mathrm{Mo}$ & $3250 \pm 500$ & $4630 \pm 680$ & $2330 \pm 120$ & $4610 \pm 270$ & $2170 \pm 210$ & $5540 \pm 660$ \\
$\mathrm{Zr}$ & $3050 \pm 240$ & $4480 \pm 330$ & $2690 \pm 130$ & $5540 \pm 260$ & $2010 \pm 110$ & $5150 \pm 370$ \\
$\mathrm{Re}$ & $2710 \pm 540$ & $3330 \pm 650$ & $1940 \pm 210$ & $3070 \pm 400$ & $1750 \pm 60$ & $3360 \pm 180$ \\
\hline
\end{tabular}


Deposited coatings are characterized by relatively high fracture toughness $\left(\mathrm{K}_{1 \mathrm{c}}\right)$. Because of difficulties with measurements of indents' dimension under load $10 \mathrm{~g}$ for calculation $\mathrm{K}_{1 \mathrm{c}}$, the load $50 \mathrm{~g}$ was selected. Exemplary micrographs of indents for zirconium and molybdenum are shown in Figure 9. As can be seen in Figure 9b, the molybdenum alloyed layers cracked during indentation. This proves low adhesion of this coating to the substrate. In the other cases the dimensions of indents are comparable but the length of the cracks are different. The shortest cracks were observed for coatings with chromium and the longest for rhenium. Based on the common Palmqvist method [21] the values of fracture toughness for coatings alloyed with zirconium, chromium and rhenium are 2.11, 1.40 and $1.77 \mathrm{MPa} \mathrm{m}{ }^{1 / 2}$ respectively. Obtained results of $\mathrm{K}_{1 \mathrm{c}}$ are similar to values of fracture toughness commonly used as protective coatings titanium nitrides [11]. It should be noted that in Palmqvist method $\mathrm{K}_{1 \mathrm{c}}$ is related to hardness (Equation (2)) and is influenced by relatively soft silicon substrate. Additionally, fracture toughness of deposited coatings might be influenced by brittle silicon substrate $\left(<1 \mathrm{MPa}^{1 / 2}\right)$.

(a)

(a)

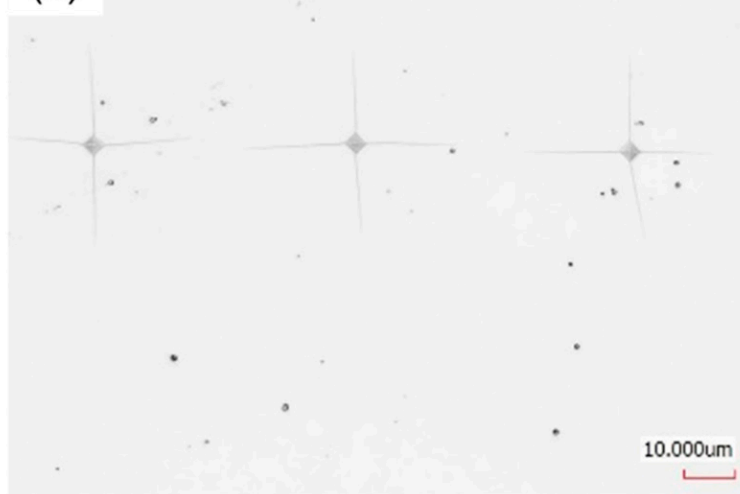

(c)

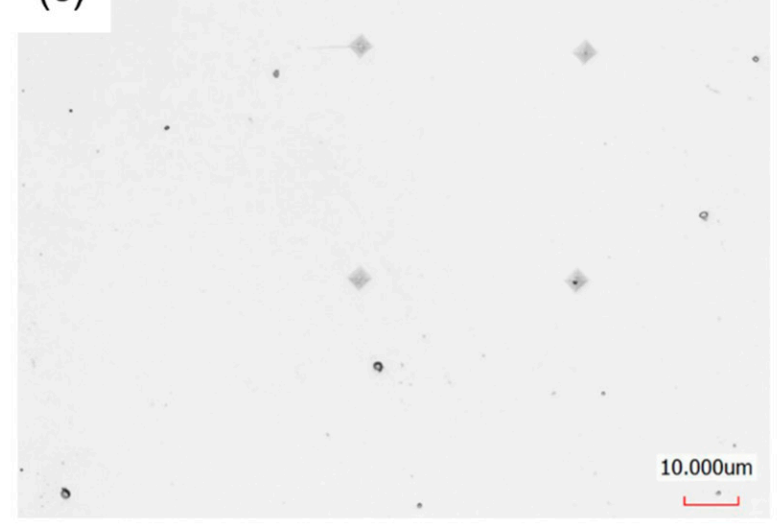

(b)

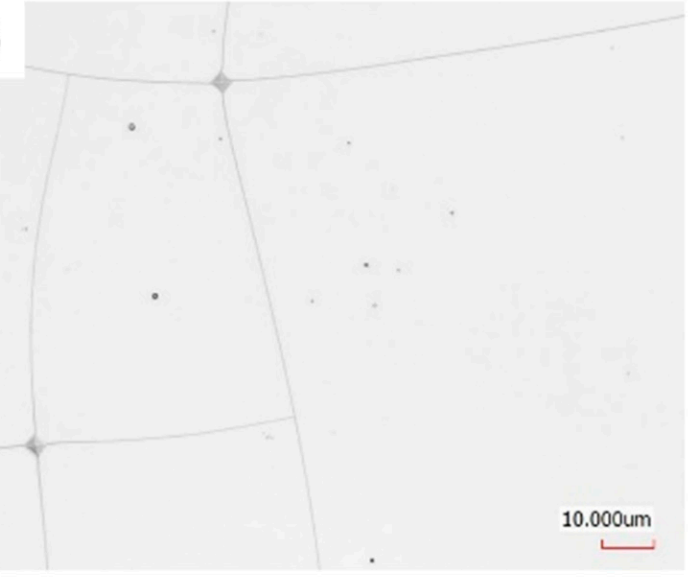

(d)

$\circ$

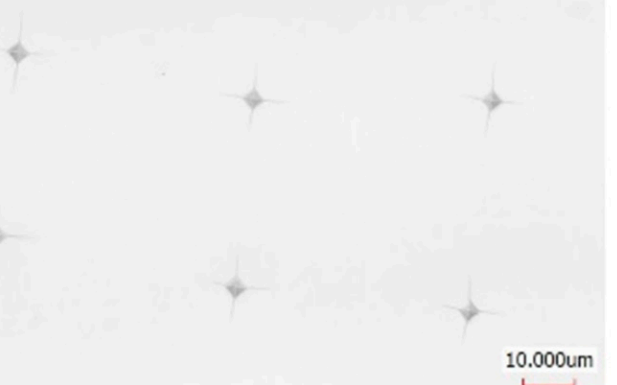

Figure 9. Confocal microscope micrographs of indented $\left(\mathrm{HV}_{0.025}\right)$ surface of coatings. (a) W-Cr-B, (b) W-Mo-B, (c) W-Re-B and (d) W-Zr-B.

\section{Conclusions}

To improve the properties of tungsten diboride, solid solutions of this material with chromium, molybdenum, rhenium and zirconium in the form of spark plasma sintered compacts and magnetron sputtered coatings were synthesized and characterized. Various concentrations of transition metal elements, ranging from 0.0 to 24.0 at. $\%$, on a metals basis, were made. Spark plasma sintering was used to synthesize these refractory compounds from the pure elements. Elemental and phase purity of the both samples (sintered compacts and coatings) were examined using energy-dispersive $X$-ray spectroscopy and X-ray diffrac- 
tion, and microindentation was utilized to measure the Vickers hardness under applied load of $2 \mathrm{~N}$ for compacts and $0.1 \mathrm{~N}$ for coatings respectively. The main observations are:

- X-ray diffraction results of SPS-ed compacts indicate that the solubility limit is below 8 at. $\%$ for molybdenum, rhenium and zirconium and below 16 at.\% for chromium. Above this limit, both diborides $(\mathrm{W}, \mathrm{TM}) \mathrm{B}_{2}$ are created.

- The addition of transition metal caused decrease of density and increase of hardness and electrical conductivity of sintered compacts.

- Deposited coatings $\mathrm{W}_{1-\mathrm{x}} \mathrm{TM}_{\mathrm{x}} \mathrm{B}_{\mathrm{y}}(\mathrm{TM}=\mathrm{Cr}, \mathrm{Mo}, \mathrm{Re}, \mathrm{Zr} ; \mathrm{x}=\sim 0.2 ; \mathrm{y}=1.7-2.0)$ are homogenous, smooth and hard. The maximal hardness was measured for $\mathrm{W}-\mathrm{Cr}-\mathrm{B}_{2}$ coatings and under the load $10 \mathrm{~g}$ was $50.4 \pm 4.7 \mathrm{GPa}$. Deposited films possess relatively high fracture toughness and for $\mathrm{WB}_{2}$ coatings alloyed with zirconium it was $\mathrm{K}_{1 \mathrm{c}}=2.11 \mathrm{MPa} \mathrm{m}^{1 / 2}$. The connection of very high hardness with high fracture toughness places these coatings in a group of novel materials with improved mechanical properties.

Due to the fact that the proposed materials possess reduced density and at the same time electrical and mechanical properties comparable or better than tungsten carbide, the presented research suggests the possibility of their implementation in everyday life. The simple and fast manufacturing process of the proposed materials should also be emphasized.

Author Contributions: Conceptualization, T.M. and R.P.; data analysis, T.M. and R.P.; investigation, R.P., J.R. and M.W.; writing_-original draft, T.M.; writing—review and editing, T.M., R.P., J.R. and D.G.; project administration, T.M. and D.G.; funding acquisition, T.M. and D.G. All authors have read and agreed to the published version of the manuscript.

Funding: This work was co-financed by the National Science Centre (NCN, Poland) under project No: UMO-2017/25/B/ST8/01789 and supported by the National Centre for Research and Development (NCBR, Poland) under project No. TECHMATSTRATEGIII/0017/2019.

Institutional Review Board Statement: Not applicable.

Informed Consent Statement: Not applicable.

Data Availability Statement: The data presented in this study are available on request from the corresponding author.

Conflicts of Interest: The authors declare no conflict of interest.

\section{References}

1. Gu, X.; Liu, C.; Guo, H.; Zhang, K.; Chen, C. Sorting transition-metal diborides: New descriptor for mechanical properties. Acta Mater. 2021, 207, 116685. [CrossRef]

2. Ivanovskii, A.L. The search for novel superhard and incompressible materials on the basis of higher borides of $s, p, d$ metals. $J$. Superhard Mater. 2011, 33, 73-87. [CrossRef]

3. Yeung, M.T.; Mohammadi, R.; Kaner, R.B. Ultraincompressible, superhard materials. Annu. Rev. Mater. Res. 2016, 46, 465-485. [CrossRef]

4. Wuchina, E.; Opila, E.; Opeka, M.; Fahrenholtz, B.; Talmy, I. UHTCs: Ultra-high temperature ceramic materials for extreme environment applications. Electrochem. Soc. Interface 2007, 16, 30-36. [CrossRef]

5. Moraes, V.; Riedl, H.; Fuger, C.; Polcik, P.; Bolvardi, H.; Holec, D.; Mayrhofer, P.H. Ab initio inspired design of ternary boride thin films. Sci. Rep. 2018, 8, 9288. [CrossRef] [PubMed]

6. Moscicki, T.; Psiuk, R.; Słomińska, H.; Levintant-Zayonts, N.; Garbiec, D.; Pisarek, M.; Bazarnik, P.; Nosewicz, S.; ChrzanowskaGiżyńska, J. Influence of overstoichiometric boron and titanium addition on the properties of RF magnetron sputtered tungsten borides. Surf. Coat. Technol. 2020, 390, 125689. [CrossRef]

7. Wicher, B.; Chodun, R.; Trzciński, M.; Lachowski, A.; Kubiś, M.; Nowakowska-Langier, K.; Zdunek, K. Design of pulsed neon injection in the synthesis of W-B-C films using magnetron sputtering from a surface-sintered single powder cathode. Thin Solid Film. 2020, 716, 138426. [CrossRef]

8. Radziejewska, J.; Psiuk, R.; Mościcki, T. Characterization and wear response of magnetron sputtered W-B and W-Ti-B coatings on WC-Co tools. Coatings 2020, 10, 1231. [CrossRef]

9. Garbiec, D.; Wiśniewska, M.; Psiuk, R.; Denis, P.; Levintant-Zayonts, N.; Leshchynsky, V.; Rubach, R.; Mościcki, T. Zirconium alloyed tungsten borides synthesized by spark plasma sintering. Arch. Civ. Mech. Eng. 2021, 21, 37. [CrossRef] 
10. Shaw, A.H. Physical Properties of Various Conductive Diborides and Their Binaries. Graduate Theses and Dissertations, Iowa State University, USA, 2015; p. 14496. Available online: https:/ /lib.dr.iastate.edu/etd/14496 (accessed on 4 November 2021).

11. Fuger, C.; Moraes, V.; Hahn, R.; Bolvardi, H.; Polcik, P.; Riedl, H.; Mayrhofer, P.H. Influence of Tantalum on phase stability and mechanical properties of $\mathrm{WB}_{2}$. MRS Commun. 2019, 9, 375-380. [CrossRef]

12. Maździarz, M.; Mościcki, T. Structural, mechanical, optical, thermodynamical and phonon properties of stable ReB 2 polymorphs from density functional calculations. J. Alloys Compd. 2016, 657, 878-888. [CrossRef]

13. Mohammadi, R.; Lech, A.T.; Xie, M.; Weaver, B.E.; Yeung, M.; Tolbert, S.H.; Kaner, R.B. Tungsten tetraboride, an inexpensive superhard material. Proc. Natl. Acad. Sci. USA 2011, 108, 10958-10962. [CrossRef] [PubMed]

14. Feng, S.; Li, X.; Su, L.; Li, H.; Yang, H.; Cheng, X. Ab initio study on structural, electronic properties, and hardness of re-doped $\mathrm{W}_{2} \mathrm{~B}_{5}$. Solid State Commun. 2016, 245, 60-64. [CrossRef]

15. Lech, A.T.; Turner, C.L.; Lei, J.; Mohammadi, R.; Tolbert, S.H.; Kaner, R.B. Superhard rhenium/tungsten diboride solid solutions. J. Am. Chem. Soc. 2016, 138, 14398-14408. [CrossRef] [PubMed]

16. Tu, Y.; Wang, Y. First-principles study of the elastic properties of $\mathrm{Os}_{\mathrm{x}} \mathrm{W}_{1-\mathrm{x}} \mathrm{B}_{2}$ and $\operatorname{Re}_{\mathrm{x}} \mathrm{W}_{1-\mathrm{x}} \mathrm{B}_{2}$ alloys. Solid State Commun. 2011, 151, 238-241. [CrossRef]

17. Smolik, J.; Kacprzyńska-Gołacka, J.; Sowa, S.; Piasek, A. The analysis of resistance to brittle cracking of tungsten doped tib 2 coatings obtained by magnetron sputtering. Coatings 2020, 10, 807. [CrossRef]

18. Psiuk, R.; Milczarek, M.; Jenczyk, P.; Denis, P.; Jarząbek, D.M.; Bazarnik, P.; Pisarek, M.; Mościcki, T. Improved mechanical properties of W-Zr-B coatings deposited by hybrid RF magnetron-PLD method. Appl. Surf. Sci. 2021, 570, 151239. [CrossRef]

19. Chrzanowska, J.; Kurpaska, Ł.; Giżyński, M.; Hoffman, J.; Szymański, Z.; Mościcki, T. Fabrication and characterization of superhard tungsten boride layers deposited by radio frequency magnetron sputtering. Ceram. Int. 2016, 42, 12221-12230. [CrossRef]

20. Wang, H.L.; Chiang, M.J.; Hon, M.H. Determination of thin film hardness for a film/substrate system. Ceram. Int. 2001, 27, 385-389. [CrossRef]

21. Palmqvist, S. Occurrence of crack formation during Vickers indentation as a measure of the toughness of hard materials. Arch. Eisenhuettenwes 1962, 33, 629-633.

22. Akopov, G.; Yeung, M.; Kaner, R.B. Rediscovering the crystal chemistry of borides. Adv. Mater. 2017, 29, 1604506. [CrossRef] [PubMed]

23. Kittel, C. Introduction to Solid State Physics, 8th ed.; Johnson, S., Ed.; John Wiley \& Sons: Hoboken, NJ, USA, 2005.

24. Maździarz, M.; Mościcki, T. New zirconium diboride polymorphs-First-principles calculations. Materials 2020, 13, 3022 [CrossRef] [PubMed]

25. Ordan'Yan, S.S.; Boldin, A.A.; Suvorov, S.S.; Smirnov, V.V. Phase diagram of the $\mathrm{W}_{2} \mathrm{~B}_{5}-\mathrm{ZrB}_{2}$ system. Inorg. Mater. 2005, 41, 232-234. [CrossRef]

26. Ken, H.; Endo, T.; Masaki, K.; Nakane, S.; Nishimura, T.; Morisada, Y.; Mizuuchi, K. Simultaneous synthesis and consolidation of $\mathrm{W}$-added $\mathrm{ZrB}_{2}$ by pulsed electric current pressure sintering and their mechanical properties. Mater. Sci. Forum 2007, 561-565, 527-530. [CrossRef]

27. Wang, C.; Song, L.; Xie, Y. Mechanical and electrical characteristics of $\mathrm{WB}_{2}$ synthesized at high pressure and high temperature. Materials 2020, 13, 1212. [CrossRef] [PubMed]

28. Bauer, A.; Regnat, A.; Blum, C.G.F.; Gottlieb-Schönmeyer, S.; Pedersen, B.; Meven, M.; Wurmehl, S.; Kunes, J.; Pfleiderer, C. Low-temperature properties of single-crystalCrB 2 . Phys. Rev. B 2014, 90, 064414. [CrossRef]

29. Levine, J.B. Synthesis and Characterization of Ultra-Incompressible Superhard Borides; Proquest, Umi Dissertation Publishing: Ann Arbor, MI, USA, 2008.

30. Rahman, M.; Wang, C.C.; Chen, W.; Akbar, S.A.; Mroz, C. Electrical resistivity of titanium diboride and zirconium diboride. J. Am. Ceram. Soc. 1995, 78, 1380-1382. [CrossRef]

31. Guimarães, B.; Fernandes, C.; Figueiredo, D.; Cerqueira, M.F.; Carvalho, O.; Silva, F.; Miranda, G. A novel approach to reduce in-service temperature in WC-Co cutting tools. Ceram. Int. 2020, 46, 3002-3008. [CrossRef]

32. Chrzanowska-Giżyńska, J.; Denis, P.; Giżyński, M.; Kurpaska, Ł.; Mihailescu, I.; Ristoscu, C.; Szymański, Z.; Mościcki, T. Thin $\mathrm{WB}_{\mathrm{x}}$ and $\mathrm{W}_{\mathrm{y}} \mathrm{Ti}_{1-\mathrm{y}} \mathrm{B}_{\mathrm{x}}$ films deposited by combined magnetron sputtering and pulsed laser deposition technique. Appl. Surf. Sci. 2019, 478, 505-513. [CrossRef]

33. Pauling, L. Atomic Radii and Interatomic Distances in Metals. J. Am. Chem. Soc. 1947, 69, 542-553. [CrossRef] 